\title{
GARAP GREGET-URIP DALAM KARAWITAN JAWA: STUDI KASUS GARAP LELAGON CAMPURSARI DALAM LOMBA GENDING DOLANAN RRI SURAKARTA
}

\author{
Widodo \\ Jurusan Pendidikan Seni Musik, Universitas Negeri Semarang \\ Email: widodo_bsejati@yahoo.com \\ Suharto \\ Jurusan Sendratasik, Universitas negeri Semarang \\ Email: suharto@mail.unnes.ac.id
}

\begin{abstract}
Abstrak
Garap sangat menentukan kualitas sajian gending. Ekspresi rasa musikalnya dalam penyajian karawitan Jawa ditentukan oleh model garap yang diterapkan. Gregeturip merupakan model garap yang penerapannya pada bagian-bagian gending dapat mengekspresikan karakter musikalnya. Permasalahannya ialah bagaimana model garap greget-urip dan kontribusinya terhadap perwujudan karakter gending. Tujuannya yaitu menemukan model garap greget-urip dan kontribusinya terhadap terwujudnya rasa gending. Masalah penelitian dibahas dalam kerangka konsep garap dan estetika karawitan Jawa. Objek kajian berupa kasus garap Lelagon Dolanan Campursari Sl. Sanga juara pertama dalam Lomba Karawitan Gendinggending Dolanan RRI Surakarta 2013 yang dirasa paling greget-urip. Data digali melalui observasi, wawancara, dan studi dokumen rekaman gending. Hasil kajian menunjukkan bahwa greget merupakan model garap benar, dinamis, kompak, menyatu dalam satu kesatuan ide garap dibawakan penuh semangat dan konsentrasi dijiwai oleh karakter gending dan bagian-bagiannya sehingga menimbulkan kesan urip atau hidup.
\end{abstract}

Kata kunci: garap, gending, greget-urip, rasa gending.

\section{A. Pendahuluan}

Garap memiliki peran signifikan dalam karawitan Jawa yang menentukan kualitas sajian gending. Secara harfiah garap berarti mengerjakan atau membuat barang material tertentu (Perlman, 1993: 163). Garap dalam karawitan Jawa menunjuk pada kerja musikal kreatif dan sistemik terdiri atas beberapa unsur dan tahap yang masing-masing saling berhubungan dan mendukung untuk mewujudkan karya karawitan berkualitas (Supanggah, 2009: 3-4). Konsep garap memiliki beberapa unsur yaitu: gending sebagai materi garap; gamelan sebagai sarana ungkap garap; vokabuler teknik, cengkok, dan wiled sebagai piranti garap; musisi karawitan sebagai penggarap; otoritas orang dan lembaga serta fungsi sosial dan layanan karawitan sebagai penentu garap; dan kondisi fisik dan psikis musisi serta keadaan situasional dan accidental sebagai pertimbangan garap. 
Gending adalah komposisi musikal karawitan Jawa berbentuk sampak, srepeg, lancaran, gangsaran, ayak-ayak, kemuda, ketawang, ladrang, jineman, ketawang gending, kethuk 2 kerep, kethuk 2 arang, kethuk 4 kerep, kethuk 4 arang, kethuk 8 kerep dan kethuk 16 kerep, dan pamijen (Rustopo, 2000: 34). Namun gending juga berarti komposisi karawitan bentuk kethuk 2 kerep dan bentuk lain yang lebih besar (Sumarsan, 2003: 345). Lelagon menunjuk pada jenis gending yang memiliki beberapa ciri, yaitu: komposisinya menekankan pada lagu vokal metrik; tema teks lagu diangkat dari peristiwa hidup keseharian diibuat dalam bahasa mudah dipahami namun kadang-kadang juga mengandung petuah moral, spiritual, dan kritik sosial diung-kapkan dalam bahasa metafora; gending berformat kecil, ketawang, lancaran, srepeg, kemuda, sampak, dan gending kecil lainnya; dan karakter musikalnya secara umum riang, gembira, meriah, lucu.

Gending memiliki unsur irama, laya, laras, pathêt, dan dinamika. Irama berkaitan dengan gradasi tempo dan isian permainan ricikan. Tempo gending yang bertingkat-tingkat membuat jarak pukul antar sabetan balungan melebar dan menyempit yang diisi oleh permainan ricikan garap dan peking dalam jumlah pukulan bertambah atau berkurang dalam kelipatan dua. Karawitan Jawa memiliki lima gradasi irama, lancar dengan lambang 1/1, tanggung 1/2, dadi 1/4, wiled 1/8, dan garap rangkep. Lambang 1/1 menunjukkan jumlah pukulan peking satu kali pada setiap sabetan balungan, demikian pula pemaknaan lambang irama lainnya (Martapangrawit, 1975: 2). Laya menunjuk kecepatan gending dalam gradasi irama yang sama, meliputi: laya tamban atau lambat, laya sedheng atau sedang, dan laya seseg atau cepat (Supanggah, 2002: 123-129). Laras berarti tangga nada sléndro-pélog dan nada-nada yang terdapat di dalamnya ditulis dalam nut Kepatihan menggunakan lambang angka-angka disebut titilaras (Sumarsam, 2003: 155-161). Pathêt yaitu suasana rasa sèlèh pada kalimat lagu gending terbangun oleh kom-binasi frasa naik, turun, gantungan, nada ageng, tengah, dan alit (Hastanto, 2009: 220). Adapun dinamika menunjukkan garap elemen-elemen musikal gending bervariasi, proporsional, dinamis.

Gamelan Jawa (ageng) memiliki beberapa bentuk ricikan, yaitu: (1) pencon meliputi: penembung, bonang barung, penerus, kenong, kempul, gong, kethuk, kempyang, engkuk, dan kemong; (2) wilah terdiri atas: gendèr barung, gendèr penerus, slenthem, demung, saron, peking, gambang; dan (3) bentuk lain 
meliputi: rebab, kendang, bedhug, siter, clempung, suling, kemanak, gong beri, dan kecer. Teknik dasar permainan ricikan pertama dan kedua dipukul dengan alat pukulnya terbuat dari bahan pokok kayu, sedangkan kelompok ricikan ketiga digesek, dikebuk dan dikeplak, dipetik, ditiup, dipukul, serta dibenturkan. Dilihat dari peran musikalnya dalam garap gending, ricikan gamelan terpilah menjadi tiga, yaitu: (1) ricikan balungan, permainannya dekat dengan susunan nada balungan gending meliputi: slenthem, demung, saron, peking, dan penembung; (2) ricikan garap, tugasnya menggarap balungan gending terdiri atas: kendang, rebab, gendèr barung, bonang barung, sindhèn, serta gendèr penerus, gambang, siter, clempung, suling, bonang penerus, gérong; dan (3) ricikan struktural, permainannya membentuk struktur bangun gending, meliputi: kethuk, kenong, kempul, gong, engkuk, kemong, kemanak, dan kecer (Supanggah, 2002: 71). Kualitas gamelan ditentukan oleh bahan, ukuran, dan larasannya yang memiliki pola interval bervariasi disebut embat (Hastanto, 2009: 22).

Ricikan gamelan memiliki teknik permainan khusus, yaitu: (1) gemakan, kecekan, dan genjotan terdapat pada ricikan balungan; (2) besutan, plurutan, sendhal pancing, kadhal mènèk, ngicrik terdapat pada rebab; dan (3) mbalung, samparan, sarugan, pipilan, genukan, ukelan, gugukan, umbaran, pêthêtan terdapat pada gendèr barung. Céngkok yaitu konfigurasi nada dan pola ritme dalam satuan panjang ter-tentu. Implementasinya dalam garap gending telah diwarnai oleh ornamentasi musikal disebut wiled. Gendèr barung memiliki vokabuler céngkok paling beragam, yakni: éla-élo, dualolo, jarik kawung, ayu kuning, kacaryan, ora butuh, tumurun, kutuk kuning, dhebyang-dhebyung, puthut gelut, puthut semèdi, gantungan, nduduk, rambatan, dan ya surakka. Céngkokcéngkok tersebut diadaptasi pada permainan rebab, gambang, siter, clempung, dan gendèr penerus. Vokabuler céngkok pada ricikan lainnya antara lain: milah, mipil, gembyang, imbal-sekaran, dan klénangan terdapat pada bonang barung; pinjalan, kinthilan, imbalan, nyacah, dan pancer terdapat pada ricikan balungan; dan polapola kendangan bentuk gending dimainkan dengan menggunakan kendang bem, gabungan bem dan ketipung, kosek dengan kendang sabet, dan ciblon dengan kendang ciblon (Sukamso, 1992: 54).

Musisi karawitan disebut pengrawit, waranggana, wiraswara. Pengrawit juga disebut wirapradangga, nayaga, niyaga, yaga, penabuh, panggamel, panjak, 
yaitu para pemain ricikan gamelan (Palgunadi, 2002: 24-27). Waranggana juga disebut pesindhèn, swarawati, seniwati, widhawati, sindhèn, yaitu vokalis (biasanya) perempuan penyaji vokal sindhènan, sedangkan wiraswara juga disebut penggérong yaitu vokalis (biasanya) pria penyaji vokal gérongan (Supanggah, 1988: ii). Peran mereka dalam penyajian karawitan menggarap gending dengan cara menafsirkan balungan gending, memilih dan menerapkan vokabuler teknik dan pola permainan pada bagian-bagian komposisi sesuai karakter dan fungsi penyajiannya sehingga membentuk jalinan suara karawitan indah sesuai rasa dasarnya.

Benamou (1998: 129-134) mengatakan, bahwa gending-gending Jawa memiliki enam kata kunci rasa musikal, yakni: (1) rêgu, mengandung unsur takut, agung, sentosa, lugu, tenang, mendalam, khidmad, klasik; (2) sêrêng, mengandung unsur kaku, tegang, marah, nafsu, semangat, takut, wibawa, polos, kasar; (3) sêdhih, mengandung unsur èmêng, gundah-gulana, empati, kasmaran, rindu, susah, sepi, dingin, sederhana, tenteram, khidmad, terharu, ngêrês; (4) prênès, mengandung unsur suka, ringan, gembira, umum, lucu, cinta, menggoda, kênès atau kemayu, sesuka hati, bebas, ramai, rongèh, sigrak, lincah, branyak, rênyah, umum, segar; (5) bérag, mengandung unsur senang, ringan, umum, rênyah, brêgas, rongèh, lincah, branyak, semangat, ramai, lucu; dan (6) gêcul, mengandung unsur lucu, bérag, gembira, sigrak, ngglécé.

Karya karawitan Jawa lahir dari proses pencarian yang diekspresikan secara simbolik melalui medium suara berlaras sléndro dan pélog (Soetarno, 2007: 13). Fungsi sajiannya tidak hanya untuk memenuhi rasa hibur melainkan uga rasa sosial, moral, kultural, dan spiritual. Komposisinya diungkapkan melalui garap. Bila garapnya rusak, maka upaya untuk mencapai karakter dan hakikat keindahannya gagal, seperti kata Sultan Agung dalam Serat Sastra Gending berikut.

Pramila gending yèn bubrah

Gugur sembahé mring Widdhi

Batal wasesaning salat

Tanpa gawé ulah gending

Déné ingaran ulah

Tukirèng swara linuhung

Amuji asmaning Dat

Swara saking osik wadi

Osik mulya wentaring cipta surasa 


\section{Terjemahan:}

Maka gending bila rusak

Rusak pula sembahnya pada Tuhan

Batal kuasanya sembah

Tanpa guna berolah gending

Adapun disebut berolah

Bersumber pada suara agung

Memuji asma Dzat

Suara dari gerak rahasia

Gerak mulia tercetusnya cipta dan rasa

Tugas garap adalah mengolah unsur-usur musikal dan kultural gending mengikuti kaidah garap yang berlaku, karakter, dan fungsi penyajiannya sehingga terbentuk jalinan komposisi bunyi karawitan indah. Greget-urip merupakan model garap yang penerapannya pada penyajian gending-gending Jawa dan bagianbagiannya dapat mengekspresikan karakter musikal untuk mencapai hakikat keindahannya sesuai fungsi penyajian. Permasalahannya yaitu bagaimana model garap greget-urip dan kontribusinya terhadap terungkapnya rasa gending? Kedua permasalahan dibahas dalam tulisan ini dalam kerangka konsep garap dan estetika karawitan Jawa.

\section{B. Metode Penelitian}

Penltian menggunakan metode deskriptif-kualitatif dengan objek kajian Lelagon Dolanan Campursari Sl. Sanga juara pertama dalam Lomba Karawitan Gending-gending Dolanan RRI Surakarta 2013 yang garapnya paling greget-urip. Data penelitian berupa garap unsur-unsur musikal dan kulturalnya serta rasa musikal yang ditimbulkan. Data digali melalui observasi, studi dokumen rekaman audiovisual garap gending, dan wawancara dengan para praktisi ahli dan pakar karawitan Jawa yang terlibat langsung dalam penggarapan gending maupun sebagai apresiatornya.

Data diidentifikasi substansi informasinya dan diklasifikasikan menjadi dua kelompok, pertama data unsur-unsur garap greget-urip yang terimplementasi pada bagian-bagian gending sebagai objek kajian, dan kedua data aspek-aspek rasa musikal yang ditimbulkan. Data diverifikasi dengan teknik triangulasi untuk me- 
mastikan validitasnya. Analisis data dilakukan dalam kerangka konsep garap dan estetika karawitan Jawa untuk menemukan model garap greget urip pada bagianbagian gending disajikan dalam peristiwa konser karawitan Jawa dan hubungannya dengan rasa musikal karawitan yang ditimbulkan. Temuan model garap greget urip dalam penyajian gending-gending Jawa dijabarkan secara deskriptifkalitatif untuk memberi gambaran kekhususan aspek garap karawitan Jawa.

\section{Model Garap Gending}

Campursari Sl. Sanga sebagai materi garap merupakan nama komposisi karawitan jenis lelagon dicipta oleh Tjokrowarsito pada tahun 1960-an ${ }^{1}$ dan diproduksi oleh Fajar Record Semarang dalam wujud rekaman pita kaset audio komersial berjudul Gending-gending Dolanan Campursari. Lelagon tersebut terletak pada indeks-1 urutan pertama diikuti Lelagon Montor-montor Cilik, Sebet, Jonjang Banyu-Wangèn, Té Katé Dipanah. Indeks-2 berisi Lelagon Hé hé Salaké, Dalan Rusak, Pulau Bali, Nelayan. Penggarapnya yaitu Condong Raos Semarang pimpinan Ki Nartosabdo. Vokal Lelagon Campursari dibawakan oleh swarawati Nyi Ngatirah. Dalam Lomba Karawitan Gending-gending Dolanan RRI Surakarta 2013, lelagon tersebut digunakan sebagai materi garap wajib untuk peserta kategori remaja diikuti oleh 22 kelompok karawitan. Gais besar komposisi vokalnya seperti berikut.

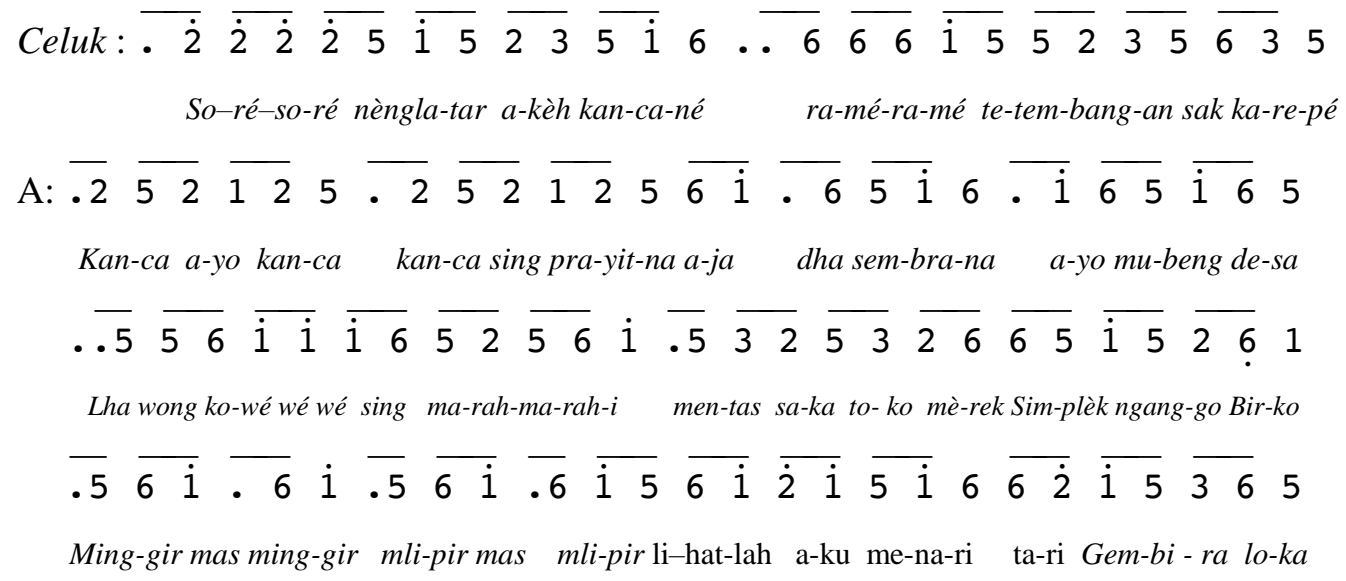
19 Juni 2013.

${ }^{1}$ Utara, ketua panitia penyelenggara lomba, dan Witoradyo, ketua dewan juri, wawancara 
Pé ta-pé ke-tan ta-pé jo-li pé ta-pé ke-tan ta-pé jo- li

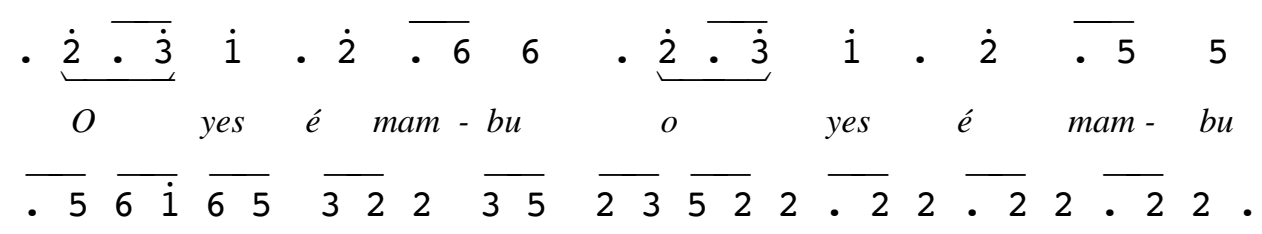

Wong-wong pa-dha gu-mun man-dheg nya-wang mon-tor-ku bib bib bib bib bib bib bib bib

Terjemahan teks

A: Sore-sore di halaman banyak temannya, beramai-ramai bernyanyi bersuka ria

Kawan mari kawan, kawan waspadalah, semua jangan lengah mari keliling desa

(Lha wong) anda yang memulai, keluar dari toko (beli sepeda) merek Simplek

pakai Birko, Minggir mas minggir, menyingkir mas menyingkir lihatlah aku

menari tari Gembiraloka

B: Pé tapé (beras) ketan tapé joli (jangan lupa), pé tapé (beras) ketan tapé joli

O ya berbau, o ya berbau

Orang-orang heran berhenti melihat motorku, bib bib bib bib (suara klakson)

Teks vokal menggambarkan suasana gembira dalam suatu permainan bersama pada sore hari di halaman rumah yang tetap ingat dan waspada terhadap keamanan lingkungan. Mereka dikejutkan oleh tingkah pengendara sepeda dengan merek Simplek memakai lampu Birko yang baru dibelinya dari toko. Ia berkendara sambil menari dan berlagak seperti naik motor menyuarakan klakson bib bib bib bib. Tingkahnya mengundang perhatian banyak orang.

Alur lagu vokal diabstraksi menjadi balungan lelagon dan dibuat dalam bentuk srepeg terbagi menjadi dua bagian. Masing-masing bagian terdiri atas tiga gongan, seperti berikut.

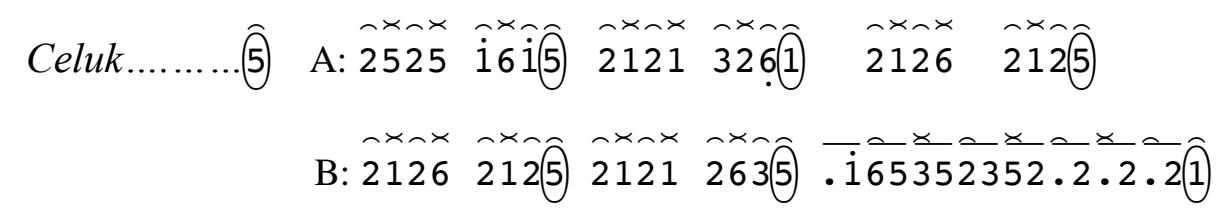

Karya juara pertama digarap oleh Sekar Dhomas, kelompok karawitan karyawan, dosen, dan mahasiswa Universitas Negeri Semarang (UNNES). Para mahasiswa sebagai anggotanya adalah aktivis organisasi Forum Unit Kegiatan Mahasiswa Kesenian Jawa (UKMKJ). Kemampuan karawitan mereka terasah melalui berbagai kegiatan, seperti: membuat karya karawitan untuk mendukung pergelaran tari dan musik mahasiswa Program Studi Tari dan Musik; menggarap 
gending ke-toprak dan pahargyan mahasiswa Jurusan Bahasa dan Sastra Jawa; menyajikan gending klenèngan dan tari pada acara rutin Slasa Legèn di UNNES dan Setu Wagèn di Pakarjawi Semarang; mendukung upacara wisuda, diesnatalis, pengu-kuhan profesor, dan lain-lain di lembaga setempat yang pelaksanaannya didukung oleh sajian karawitan; serta mengisi berbagai acara hajatan masyarakat di Kota Semarang dan sekitarnya. Karena peserta yang diikuti kategori remaja dengan batasan usia maksimal 25 tahun, maka anggota tim karawitan pada acara tersebut didukung oleh para mahasiswa berjumlah 22 orang, terdiri atas 5 vokalis putri, 3 vokalis putra, dan 14 pemain ricikan.

Konser karawitan dalam lomba karawitan di atas menggunakan sarana ungkap gamelan lengkap dan berkualitas terdiri atas beberapa ricikan, yaitu: kendang bem, sabet, ciblon, dan ketipung, rebab, tiga rancak gendèr barung dan gendèr penerus sléndro, pélog barang, dan pélog bem, dua rancak bonang barung dan penerus sléndro dan pélog, dua rancak slenthem sléndro dan pélog, empat rancak demung sléndro dan pélog, delapan rancak saron sléndro dan ncak pélog, dua rancak peking sléndro dan pélog, kethuk-kempyang sléndro dan pélog, kenong dan kempul-gong sléndro dan pélog lengkap, tiga rancak gambang sléndro, pélog barang, dan pélog bem, sebuah siter, dan suling sléndro dan pélog. Ricikan pencon dan bilah terbuat dari logam perunggu dengan larasan pleng dibuat dalam embat Larasati. Ricikan lain dibuat dari bahan pokok kayu, kulit, kawat atau dawai, bambu, dan campuran.

Lelagon disajikan dalam tiga putaran. Putaran pertama digarap seperti garap gending yang dicontohkan dalam rekaman pita kaset audio komersial relatif tanpa pengembangan dengan tujuan menunjukkan garap aslinya. Pengembangan garap secara rinci ditunjukkan pada putaran kedua dan ketiga. Secara garis besar model garapnya secara utuh seperti berikut.

\section{Garap vokal}

Putaran pertama diawali buka celuk oleh vokalis tunggal putri yang alur lagunya dibawakan dalam kombinasi suara ritmik dan metrik diberi beberapa jeda. Jeda pertama pada akhir teks soré-soré diakhiri suara tidak bernada naik lalu turun menguat tidak bernada. Karakter suara vokalisnya yang trègèl, kenès menimbulkan kesan nakal, gecul. Bagian lanjutannya disajikan secara ritmik hingga jeda kedua pada akhir teks neng latar akeh kancané dan dilanjutkan alur lagu metrik 
untuk direspon oleh kendang dan diteruskan pada penyajian gending bersama. Vokal A disajikan secara koor oleh vokalis wanita bersama pria. Pada menjelang gong terakhir, tempo diperlambat untuk beralih pada B garap rangkep. Vokal B dibawakan oleh koor vokalis wanita dan pria secara bergantian. Koor wanita membawakan bagian lagu dengan teks pé tapé ketan, dan koor pria pada tapé joli, teks o yes oleh koor pria, dan é mambu oleh koor wanita. Vokal B dibawakan koor wanita bersama pria hingga suwuk.

Buka celuk pada putaran kedua dibawakan oleh vokalis tunggal putra dengan model garap hampir sama dengan putaran pertama, namun pada jeda kedua diberi tambahan komposisi sebagai isian jeda dibawakan oleh koor vokalis putri seperti berikut.

$$
\begin{aligned}
& \text { - } 2 \text {. } 3 \text {. } 5 \text { i } \overline{6 i} 6 \ldots \\
& \text { Pa-dha mré-né é }
\end{aligned}
$$

Tiga titik di belakang notasi vokal di atas disajikan dalam suara panjang bernada nem diakhiri tekanan menguat naik lalu turun tidak bernada menimbulkan kesan gecul. Bagian lanjutannya dibawakan secara metrik untuk dilanjutkan permainan gending bersama. Vokal A diberi tambahan komposisi dibuat dalam aksen kempyung terhadap lagu vokal asal. Teks lagu diambilkan dari bagian cakepan lagu vokal asal. Lagu vokal asal dibawakan oleh koor vokalis putra dan tambahannya oleh koor vokalis putri membentuk perpaduan suara susulmenyusul, seperti berikut.

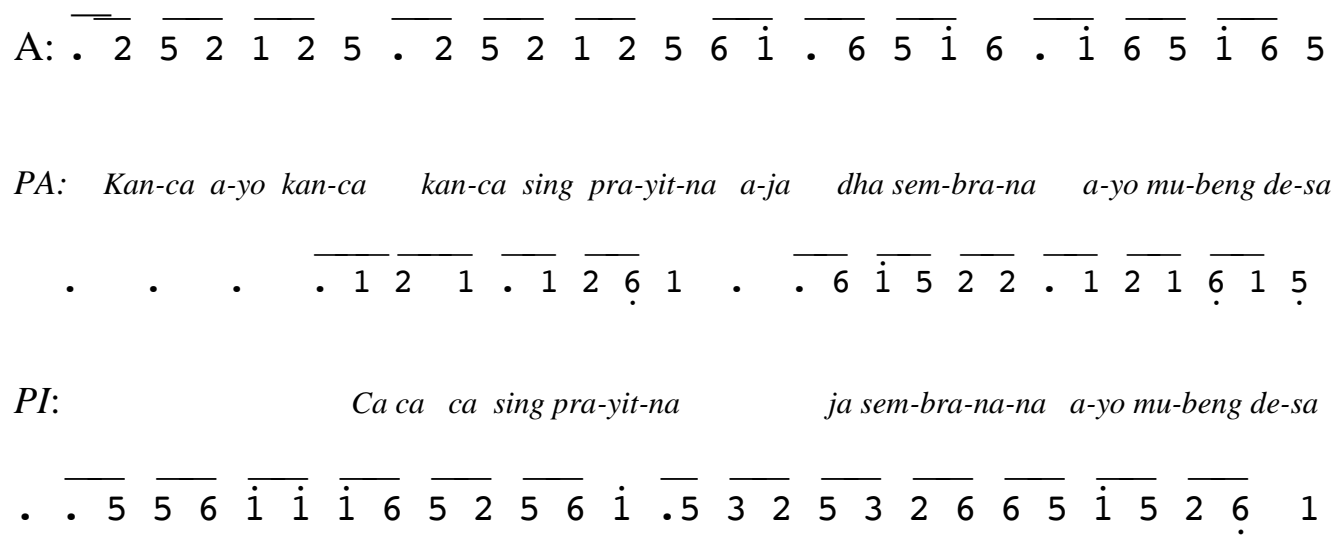

PA: Lha wong ko-wé wé wé sing ma-rah-ma-rah-i men-tas sa-ka to-ko mè-rek Sim-plèk ngang-go Bir-ko

$\overline{.} 1 \overline{23} 5 . \quad .3 \overline{21} \overline{23} 5 . \quad \cdot \quad \cdot \quad \overline{i 6 \dot{1}} 6 \overline{65} \overline{32} 5$ 


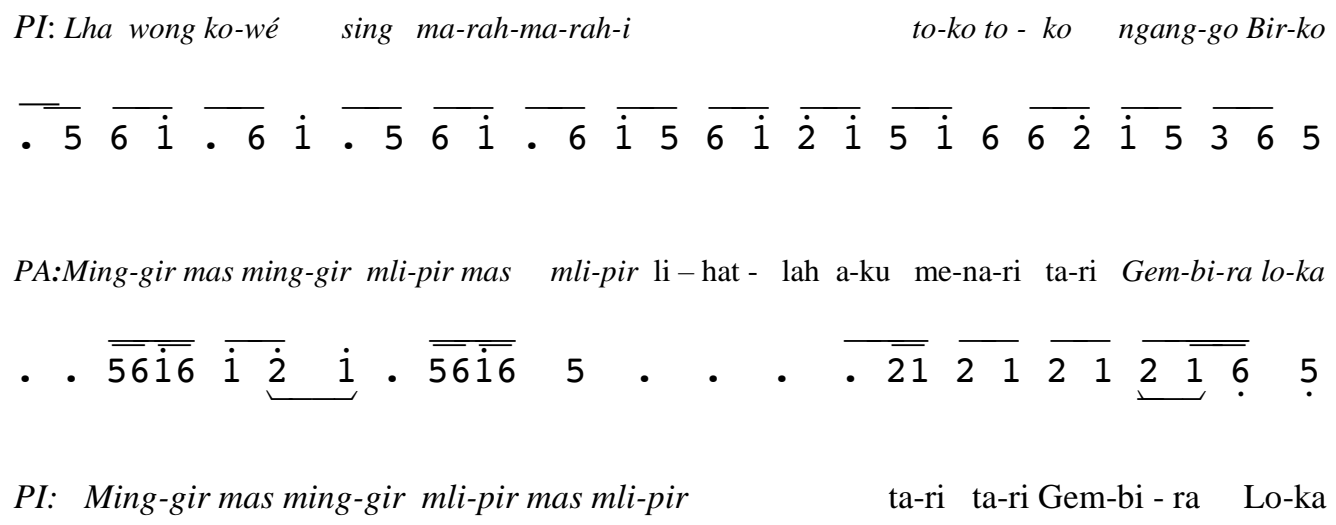

PA : Pria, PI: wanita

Vokal B juga diberi tambahan komposisi untuk mengisi ruang kosong pada lagu vokal asal dibawakan secara koor oleh vokalis pria. Garis besar komposisinya seperti berikut.



Pada teks vokal bib bib baris terakhir, vokalis putra menyuarakan nada gulu, dan para vokalis putri menyuarakan nada nem, dua nada berposisi kempyung yang perpaduannya menghasilkan kesan bunyi indah hingga suwuk.

Putaran ketiga diawali buka celuk dengan alur lagu, tempat jeda, dan komposisi tambahan sama dengan putaran kedua namun peraganya dibalik, vokal asal dibawakan oleh vokalis tunggal putri dan vokal tambahannya oleh vokalis tunggal putra. Vokal A gongan pertama dibawakan oleh vokalis tunggal putri dan tambahannya oleh tunggal putra, demikian pula baris kedua. Pada baris ketiga, vokal asal dibawakan oleh koor putri dan vokal tambahannya oleh koor putra. Pada B lagu asal dibawakan koor putra dan vokal tambahannya oleh koor putri.

2. Garap ricikan

Lelagon putaran pertama disajikan dalam bentuk srepeg irama dadi. Kendang pada bagian ini bermain pola pematut dikombinasikan pola kèngser dan kawahan pada menjelang aksen-aksen lagu; ricikan balungan bermain susunan nada balungan gending; bonang barung dan bonang penerus bermain imbalsekaran namun pada gongan terakhir gembyang; gendèr barung, siter, dan 
gambang memainkan pola permainan mengacu pada gatra dan nada-nada sèlèh balungan gending dengan pemberian wiled bervariasi mengikuti dinamika garapnya.

Bentuk geding pada putaran kedua digarap lancaran dan disajikan dalam gaya karawitan Semarangan dilanjutkan langgam irama rangkep sejak dua sabetan balungan menjelang gong terakhir A hingga B gongan kedua. Susunan nada balungan gending bentuk lancaran hasil gubahan seperti berikut.

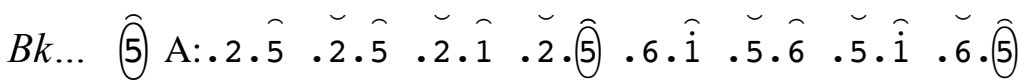

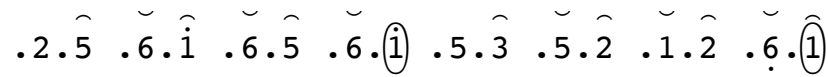

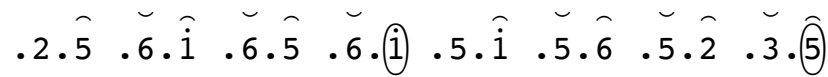

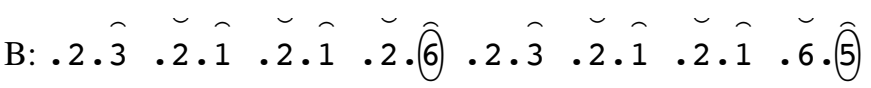



$$
\begin{aligned}
& \begin{array}{lllllllllllllllllll} 
& 1 & 6 & 5 & 3 & 5 & 2 & 3 & 5 & 2 & \bullet & 2 & \bullet & & 2 & \bullet & 2 & & (1)
\end{array}
\end{aligned}
$$

Bonang barung dan penerus sejak awal A hingga menjelang gong terakhir bermain imbal-sekaran dilanjutkan pola langgam garap rangkep. Kendang, bonang barung, dan bonang penerus memainkan jalinan komposisi seperti permainan cello, cuk, dan cak pada musik keroncong. Pola gembyang kembali dimainkan pada menjelang gongan kedua B hingga suwuk dalam garap bentuk gending srepeg.

Putaran ketiga, ricikan struktural pada A bermain pola lancaran gaya Surakarta dilanjutkan Banyumasan pada B gongan pertama dan kedua. Pada akhir buka celuk, kendang memberi isyarat garap sirep diikuti permainan ricikan struktural dan vokal tunggal putra diselingi vokal tunggal putri dan disusul gendèr barung, siter, dan gambang pada menjelang gong pertama. Bonang barung dan penerus menyusulnya dengan bermaian imbal-sekaran pada menjelang akhir 
gongan kedua, dan terakhir disusul ricikan balungan. Gongan terakhir kembali digarap srepeg irama tanggung hingga suwuk.

\section{Garap Greget-Urip}

Dilihat dari alur lagu dan makna teks vokalnya, Lelagon Campursari, Sl. Sanga berkarakter gecul atau lucu, riang. Agar para peserta dapat mengekpresikan karakternya secara maksimal dalam penyajian, balungan gending dan contoh garapnya dalam rekaman audio diberikan jauh sebelum kompetisi digelar sebagai bahan eksplorasi garap. Hasil garapan mereka yang tersaji dalam konser karawitan beragam, sebagian mengikuti contoh garap yang terdapat dalam rekaman audio, sebagian pengembangan garapnya jauh dari rasa estetik dan kultural gending, dan sebagian digarap kreatif dalam kerangka estetika karawitan Jawa. Dibanding 21 karya lainnya, garap Lelagon Campursari, Sl. Sanga juara pertamanya dirasa paling memenuhi kriteria garap greget-urip.

Hasil kajian garap menemukan beberapa ciri model garapnya, yaitu: pertama, garap lelagon asal sebagaimana terdapat dalam contoh rekaman audio diperlakukan sebagai materi garap yang digarap ulang secara kreatif meliputi hampir semua unsur musikalnya, vokal, bentuk, gaya karawitan, genre musik, irama, tempo, volume, dan dinamika. Pengembangan garap unsur-unsur musikal tersebut ditunjukkan pada putaran kedua dan ketiga dalam kerangka kaidah garap yang berlaku dan rasa estetik gending sebagai karakternya.

Kedua, garap vokal menyangkut pemberian wiled dan tambahan komposisi pada bagian-bagian lagu dibuat dalam alur lagu dan aksen-aksen musikal terpadu dengan komposisi lagu asal. Sebagian alur lagu diberi aksen musikal menguat naik lalu turun tidak bernada menimbulkan kesan gecul; sebagian lainnya dibuat dalam perpaduan sèlèh kempyung menimbulkan jalinan suara indah. Secara umum alur lagu vokal dibawakan dalam suara pleng, jelas, tegas dalam nada-nada laras sléndro pathêt sanga, dan teks vokal terucap wijang sesuai kaidah pengucapan kata dalam bahasa Jawa. Komposisi disajikan oleh para vokalis dalam cara pembawaan bervariasi, tunggal putri, tunggal putra, koor putri, koor putra, koor gabungan putri dan putra, serta susul-menyusul yang menimbulkan kesan dinamis.

Ketiga, bentuk gending asal, srepeg diubah menjadi lancaran diikuti oleh perubahan struktur dan susunan nada balungan gending serta pola permainan 
ricikan struktural. Keduanya diterapkan pada bagian-bagian komposisi secara kombinatif. Pola-pola permainan sebagai penunjuk bentuk gending tersebut terekspresi secara benar, jelas, dan kompak sesuai kaidah garap yang berlaku.

Keempat, gaya karawitan daerah Banyumas, Semarang, dan genre musik keroncong dihadirkan dalam garap gending melalui adaptasi pola permainan instrumen dominan sebagai pembentuk ciri khas garapnya. Karawitan Banyumasan dihadirkan melalui adaptasi pola permainan kendang, bonang barung, bonang penerus, kenong, kempul, dan saron; karawitan Semarangan melalui permainan kendang, bonang barung, bonang penerus dan kempul-gong; dan musik keroncong melalui abstraksi pola permainan cak, cuk, dan cello ke dalam permainan bonang barung, bonang penerus, dan kendang.

Kelima, garap irama, laya, dan volume bervariasi. Bagian-bagian gending digarap dalam irama tanggung, dadi, dan rangkep dengan peralihan dibuat beragam, halus mengalir dan kontras dalam garap laya cepat, sedang, dan lambat serta volume keras, sedang lembut. Garap demikian menimbulkan kesan musikal dinamis.

Keenam, vokabuler céngkok pada ricikan garap dipilih dan diterapkan secara benar pada bagian-bagian gending mengikuti struktur dan susunan nada balungannya dengan pemberian wiled bervariasi mengikuti dinamika garapnya. Garap céngkok dan wiled pada ricikan garap lagu berada dalam kerangka pathêt induk gending, slèndro sanga sehingga tidak ada bagian jalinan komposisinya yang terasa janggal menurut perspektif rasa pathêt.

Model garap gending diungkapkan penuh konsentrasi, semangkat, dan penghayatan dijiwai oleh karakter dasar gending sehingga jalinan komposisinya dinamis, hidup. Garap gending demikian disebut oleh Ki Witoradyo, ketua Dewan Juri dalam Kompetisi Karawitan Gending-gending Dolanan RRI Surakarta 2013 sebagai greget-urip. Greget secara harfiah artinya penuh semangat, daya, tenaga, dan hayatan; sedangkan urip berarti hidup (KBBI). Berdasarkan hasil kajian garap gending di atas dapat dinyatakan, bahwa greget menunjuk pada model garap gending yang mengandung beberapa unsur garap, yaitu: (1) benar, garap pada bagian-bagian gending sesuai kaidah garap yang berlaku dalam karawita Jawa; (2) wijang, permainan ricikan dan vokal jelas sesuai karakter dan fungsi musikalnya; (3) rempeg, garap pada bagian-bagian gending kompak dan menyatu dalam satu 
kesatuan ide garap; (4) dinamis, garap pada unsur-unsur musikal gending bervariasi dan proporsional; dan (5) hidup, model garap pada bagian-bagian komposisi dibawakan dengan penuh semangat dan penghayatan dijiwai oleh karakter komposisi dan bagian-bagiannya.

\section{E. Kesimpulan}

Implementasi model garap greget-urip pada gending-gending Jawa dalam penyajian konser karawitan dapat mengekspresikan rasa musikal dan kulturalnya secara kuat dan mantap. Model garap tersebut memiliki beberapa unsur, yaitu benar, bagian-bagian gending digarap secara benar sesuai kaidah garap yang berlaku dalam karawita Jawa; wijang, garap ricikan dan vokal jelas sesuai karakter dan fungsi musikalnya; rempeg, garap bagian-bagian gending kompak dan menyatu dalam satu kesatuan ide garap; dinamis, garap pada bagian-bagian gending bervariasi dan proporsional; dan hidup, model garap pada bagian-bagian komposisi dibawakan dengan penuh konsentrasi, semangat, dan penghayatan dijiwai oleh karakter komposisi dan bagian-bagiannya. Penerapan model garap tersebut pada Lelagon Campursari, Sl. Sanga karya juara pertama dalam lomba karawitan di atas dapat mengekspresikan karakter komposisinya yang gecul, riang, lucu secara kuat dan mantap dalam penyajian konser karawitan. 


\section{DAFTAR PUSTAKA}

Benamou, Marc. (1998), "Rasa in Javanese Musical Aesthetics", Dissertation, UMI Company, Ann Arbor, The University of Michigan.

Brinner, Benjamin. (1995), Knowing Music Making Music Javanese Gamelan and The Theory of Musical Competence and Interaction, The University of Chicago Press, Chicago.

Harjito, Priadi Dwi. (2001), "Kebinekaan Laras, Keserupaan Laras, dan Metode Penetapannya", Makalah, STSI Bandung, Bandung.

Hastanto. Sri. (2009), Konsep Pathet dalam Karawitan Jawa, ISI Surakarta Press, Surakarta.

---------2009, "Penelitian Pengertian Konsep Embat dalam Karawitan Jawa". Makalah. ISI Surakarta, Surakarta.

Martapangrawit.(1975). "Pengetahuan Karawitan”, ASKI Surakarta, Surakarta.

Palgunadi, Bram. (2002), Serat Kandha Karawitan Jawi, ITB, Bandung.

Perlman, Marc. (1993), "Unplayed Melodies Music Theory in Post Colonial Java", Dissertation, Wesleyen University, Wesleyen.

Soetarno, Sunardi, \& Sudarsono. (2007), Estetika Pedalangan, CV Adji, Surakarta.

Stange, Paul. (1998), Politik Perhatian Rasa dalam Kebudayaan Jawa, LKIS, Yogyakarta.

Sukamso.(1992), "Garap Rebab, Kendhang, Gendèr, dan Vokal dalam Gendhing Bondhet", Laporan Penelitian, STSI Surakarta, Surakarta.

Sumarsam. (2003), Gamelan, Interaksi Budaya dan Perkembangan Musikal di Jawa, Pustaka Pelajar,Yogyakarta.

Sunardi. (2012), "Nuksma dan Mungguh: Estetika Pertunjukan Wayang Purwa Gaya Surakarta", Disertasi, UGM, Yogyakarta.

Supanggah, R. (2002), Bothekan Karawitan I, MSPI, Jakarta.

------. (2009), Bothekan Karawitan II: Garap. Surakarta, PPS ISI Surakarta \& ISI Surakarta Press, Surakarta.

Susena, Franz Magnis. (2003), Etika Jawa sebuah Analisa Falsafi tentang Kebijaksanaan Hidup Orang Jawa, Gramedia Pustaka Utama, Jakarta.

Suharto. (2013). Suara Emas dari Unnes Sinden Contest (Sinden Idol).FLV - YouTube.

Retrieved June 6, 2017, from https://www.youtube.com/watch?v=4Cb7nw1tfhU

Suharto, S. (2016). Banyumasan Songs As Banyumas People's Character Reflection.

Harmonia: Journal of Arts Research and Education, 16(1), 49-56.

Suwardi,A.L. (2000), “Teknik Tabuhan dan Tutupan Gender”, STSI, Surakarta.

Widada. (2001). Kamus Basa Jawa (Bausastra Jawa), Kanisius, Yogyakarta.

Winter \& Ranggawarsita. (1994), Kamus Kawi-Jawa, Gadjah Mada University

Press, Yogyakarta.

Wiryomartono, Bagoes P. (2001), Pijar-pijar Penyingkap Rasa, Gramedia Pustaka Utama, Jakarta.

Woodward, Mark R. (1999), Islam Jawa, Kesalehan Normatif Versus Kebatinan, LKIS, Yogyakarta.

Zoetmulder. (2000), Kamus Jawa Kuna-Indonesia, Gramedia, Jakarta.

Widodo \& Suharto. (2015). Laras in Gamelan Music's Plurality. Harmonia: Journal Of Arts Research And Education, 15(1), 34-45.

doi:http://dx.doi.org/10.15294/harmonia.v15i1.3695 
Widodo, W., Ganap, V., \& Soetarno, S. (2017). Laras concept and its triggers: A case study on garap of jineman Uler Kambang. Harmonia: Journal Of Arts Research And Education, 17(1), 75-86. doi:http://dx.doi.org/10.15294/harmonia.v17i1.10771 